\title{
THE EVALUATION OF PERCEPTIONS' SUSTAINABLE RURAL AND URBAN INTERFACE OF THE URBAN INHABITANTS IN THE PERIPHERY OF KONYA
}

\author{
Çiğdem Çiftçi ${ }^{*}$, Laura Shumka ${ }^{2}$, Spase Shumka $^{3}$, Şükrü Dursun ${ }^{4}$, Elson Salihaj ${ }^{5}$ \\ ${ }^{I}$ Necmettin Erbakan University, Department of Urban and Regional Planning, Konya, Turkey; \\ ${ }^{2}$ Albanian University of Tirana, Department of Architecture, Tirana, Albania; \\ ${ }^{3}$ Agriculture University of Tirana, Department of Animal Sciences and Fishery, Tirana, Albania; \\ ${ }^{4}$ Konya Technical University, Environmental Engineering Department, Konya, Turkey; \\ ${ }^{5}$ Natural, IPA 2013 - Natura 2000 and Protected Areas Torre Drin, Tirana, Albania;
}

*Corresponding author Çiğdem Çiftçi e-mail: cigdemciftci@erbakan.edu.tr;

Received August 2019; Accepted September 2019; Published October 2019;

DOI: https://doi.org/10.31407/ijees9403

\begin{abstract}
The disintegrating of rural and urban space is the main problem area of the urban environment. The behavior of users living in the periphery directly affects the sustainable spatial integration of these rurban areas. Ecological based spatial modeling of rural urban continuity defines urban growth strategies. In this context, environmental consciousness of the rurban dwellers in the periphery is one of the important indicators of the sustainability of the ecological structure of the urban environment in the periphery. In this study, urban land use behaviors and expectations of the inhabitants of Kayacık and Tatlicak villages, which are located at rurban areas in Konya, will be evaluated as to NEP Scale' analysis method. Tatlıcak is an exurbia, which was settled low-income groups by the metropolitan municipality; Kayacık is a villiage at the edge of city before the 6360 Metropolitan Law in 2012. After the 6330 numbered Law, metropolitan administration border expanded to the provincial borders administratively. In this study, 5-point Likert-scale NEP analysis of nature-centered and human-centered land use approaches to sample size in $10 \%$ of both village population is examined and it is examining environmentally sensitive behaviors.
\end{abstract}

Keywords: Konya peri-urbanisation, urban environment identity, nature-centered perception, human-centered environmental perception. 